\title{
Fasciculations, myalgia and biochemical changes following succinylcholine with atracurium and lidocaine pretreatment
}

\author{
$S$ K Raman MB BS FFARCS(Ire), \\ W M San MB BS MMED(Anaes) FANZCA
}

\begin{abstract}
Purpose: To determine the attenuation in the incidence of myalgia, fasciculations and changes in serum potassium and creatinine kinase concentrations when atracurium and lidocaine were used in combination and separately as pretreatment before succinylcholine.
\end{abstract}

Method: In a prospective, double blind randomized study, $80 \mathrm{ASA}$ I patients $20-50 \mathrm{yr}$ were assigned to one of four groups. Anaesthesia was induced with thiopentone and fentanyl. Group $C$ received placebo pretreatment before $1.5 \mathrm{mg} \cdot \mathrm{kg}^{\prime}$ succinyicholine; Group A $0.05 \mathrm{mg} \cdot \mathrm{kg}^{-1}$ atracurium three minutes before: Group L, 1.5 $\mathrm{mg} \cdot \mathrm{kg}^{-1}$ lidocaine $30 \mathrm{sec}$ before; and group AL both atracurium and lidocaine. Serum potassium five minutes after succinylcholine, and creatinine kinase $24 \mathrm{hr}$ after operation were measured and the increases from preinduction values were compared. Fasciculations and postoperative myalgia at 24 and $48 \mathrm{hr}$ were recorded. Patients received iv meperidine or po paracetamol for postoperative analgesia.

Results: The increase in serum potassium concentration $\left(0.36 \pm 0.23 \mathrm{mEq} \cdot{ }^{-1}\right)$ was not attenuated by any regimen $(P<0.05)$. The incidence of fasciculations $(P<0.05)$ and the increase in creatinine kinase $(P<0.01)$ was less in the atracurium (40\%; $\left.20.93 \mathrm{IU} \cdot \mathrm{I}^{-1}\right)$ and atracurium-lid ocaine $\left(30 \% ; 22.85 \mathrm{IU} \cdot \mathrm{H}^{-1}\right)$ than in the lidocaine $(85 \%$; 45.0IIU. ' $)$ and control (100\%; $56.05 \mathrm{IU}^{-1}$ ) groups. Postoperative myalgia on Days 1 and 2 was lowest $(P<0.05)$ in the atracurium-lidocaine group $(5 \% ; 0 \%)$ followed by the atracurium $(35 \% ; 25 \%)$ and lidocaine (30\%; 35\%) groups and highest in the control $(75 \% ; 65 \%)$.

Conclusion: Atracurium and lidocaine individually reduce postoperative myalgia, with further decrease occurring when used together.

Objectif : Déterminer le degré d'atténuation de la myalgie, des fasciculations, des variations de la kaliémie et des concentrations de la créatine kinase lorsque l'atracurium et la lidocaïne sont administrés conjointement ou séparément avant la succinylcholine.

Méthodes : Au cours d'une étude aléatoire prospective en double aveugle, 80 patients ASA I âgés de 20 à 50 ans ont été assignés à un de quatre groupes. L'anesthésie étart induite au thiopentone et au fentanyl. Le groupe $C$ a reçu un placebo avant l'administration de $1,5 \mathrm{mg} \cdot \mathrm{kg}^{-1}$ de succinylcholine ; le groupe A, de l'atracurium 0,005 $\mathrm{mg} \cdot \mathrm{kg}^{\prime}$ trois minutes avant : le groupe $\mathrm{L}$, de la lidocainne $1,5 \mathrm{mg} \cdot \mathrm{kg}^{-1} 30 \mathrm{sec}$ avant et le groupe $\mathrm{AL}$, à la fois l'atracurium et la lidocaïne. On a mesuré la kaliémie cinq minutes après la succinylcholine et la créatine kinase $24 \mathrm{~h}$ après l'opération et comparé les valeurs avec celles qui précédaient l'induction. On a noté les fasciculations et la myalgie préopératoire. Lanalgésie postopératoire été réalisée avec de la mépéridine iv ou du paracétamol po.

Résultats : Aucun des régimes n'a atténué l'augmentation de la kaliémie $(90,36 \pm 0,23 \mathrm{mEq} . \mathrm{L}-\mathrm{I}, P<0,05)$. Lincidence des fasciculations $(P<0,05)$ et l'augmentation de la créatine kinase étaient moins élevées dans les groupes atracurium $\left(40 \% ; 20,933 \mathrm{UI} \cdot \mathrm{L}^{-1}\right)$ et atracurium-lidocaine $\left(30 \% ; 22,85 \mathrm{UI} \cdot \mathrm{L}^{-1}\right)$ que dans les groupes lidocaïne $\left(85 \% ; 45.01 \mathrm{UI} \cdot \mathrm{L}^{-1}\right)$ et contrôle $\left(100 \% ; 56.05 \mathrm{UI} \cdot \mathrm{L}^{-1}\right)$. La myalgie postoperatoire aux jours I et 2 était la moins fréquente $(P<0.05)$ dans le groupe atracurium-lidocaine $(5 \% ; 0 \%)$ suivi des groupes atracurium $(35 \% ; 25 \%)$ et lidocaine $(30 \% ; 35 \%)$ et la plus fréquente dans le groupe contrôle $(75 \% ; 65 \%)$.

Conclusion : Latracurium et la lidocaine diminuent individuellement la myalgie postopératoire mais sont plus efficace lorsqu'ils sont administrés conjointement.

From the Department of Anaesthesia, Tan Tock Seng Hospital, 7 Mandalay Road Singapore 308207.

Address correspondence to: Dr. Sitaram K Raman, Department of Anaesthesia, Singapore General Hospital, Outram Road, Singapore 169608 .

Accepted for publication February 8, 1997. 


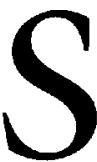

UCCINYLCHOLINE induced myalgia is a well known complication ${ }^{1}$ with an incidence ranging from 5 to $83 \% .^{2}$ The drug is also associated with biochemical changes such as raised serum creatinine kinase and hyperkalaemia. ${ }^{1,3-7}$

Many studies using various drugs such as nondepolarizing agents and lidocaine, have been conducted in an attempt to reduce the intensity of the myalgia and the muscle damage. ${ }^{8-14}$ There has been only one study using two agents, lidocaine and d-tubocurarine, to decrease the incidence of myalgia..$^{15}$ Atracurium, a non depolarising muscle relaxant, and lidocaine, a commonly used local anaesthetic agent, have been shown ${ }^{11,13,14,16}$ independently, to reduce the incidence of succinylcholine induced myalgia.

The purpose of this study was to determine if atracurium and lidocaine together, would better attenuate the incidence of myalgia, fasciculations and changes in serum potassium and creatinine kinase concentrations than when used separately, as pretreatment for succinylcholine.

\section{Methods and materials}

We studied 80 ASA physical status I patients, aged 25-50 yr, after obtaining Institutional Review Board Ethics Committee approval and written informed consent. All patients were scheduled for ENT surgery lasting about one hour with tracheal intubation being required. This type of surgery was selected as there was minimal risk of surgical induced increase in creatinine kinase concentration. Patients with cardiorespiratory or neuromuscular disease, severe drug allergies, symptoms of gastro-oesophageal reflux or anatomical features that might make tracheal intubation difficult were excluded.

Each patient was assigned to one of four pretreatment groups in a prospective, double blind, randomized manner. Each group of patients received two injections, one three minutes and the other $15 \mathrm{sec}$ before succinylcholine was administered. Group $\mathrm{C}$, the control group, received normal saline three minutes before and again at $15 \mathrm{sec}$; Group A, atracurium 0.05 $\mathrm{mg} \cdot \mathrm{kg}^{-1}$ and normal saline; Group L, normal saline and lidocaine $1.5 \mathrm{mg} \cdot \mathrm{kg}^{-1}$; Group $\mathrm{AL}$, atracurium 0.05 $\mathrm{mg} \cdot \mathrm{kg}^{-1}$ and lidocaine $1.5 \mathrm{mg} \cdot \mathrm{kg}^{-1}$. All pretreatment medication was administered in a double-blind fashion from syringes containing solutions diluted to the same volume.

The patients received no premedication. On arrival in the anaesthetic room, an intravenous canula was inserted into a large vein in the antecubital fossa for sampling blood. A vein on the other arm was cannulated for administration of anaesthetic agents and intra- venous fluids. All patients were monitored with ECG, non invasive blood pressure, (Dinamap, Critikon Inc., Tampa Fl USA), peripheral nerve stimulator (Dakmed, Dakmed Inc., Buffalo, NY USA), pulse oximetry and end-tidal carbon dioxide monitors. Anaesthesia was induced with $4-5 \mathrm{mg} \cdot \mathrm{kg}^{-1}$ thiopentone $i v$, followed by $1.5 \mathrm{mg} \cdot \mathrm{kg}^{-1}$ succinylcholine. Onset of neuromuscular blockade was evaluated by observing one second twitch responses to supramaximal stimulus of the ulnar nerve via cutaneous electrodes. Tracheal intubation was performed when no neuromuscular response was seen. Anaesthesia was maintained with nitrous oxide $66 \%$ in oxygen and isoflurane $1-2 \%$ with incremental doses of fentanyl given as required. Atracurium was given in incremental doses, with monitoring of the neuromuscular blockade, after the succinylcholine had worn off. Postoperatively, for the first $24 \mathrm{hr}$, incremental doses of meperidine iv were administered for analgesia while metoclopramide ip was administered for nausea. For the next $24 \mathrm{hr}$, paracetemol po was given for analgesia.

Following administration of succinylcholine, the presence, degree and duration of fasciculations were assessed visually on a four point scale by one of the authors who was double blinded to the drugs: 0 no visible fasciculations, 1 (mild) very fine finger tip or facial muscle movement; 2 (moderate) minimal fasciculations on the trunk and extremities; 3 (severe) vigorous fasciculations on the trunk and extremities.

Blood samples for serum potassium were drawn, without stasis, before induction of anaesthesia and five minutes after succinylcholine administration. Blood samples for creatinine kinase were drawn before induction and $24 \mathrm{hr}$ postoperatively. The increases in serum potassium and creatinine kinase were calculated by subtracting the five minute postsuccinylcholine potassium results and the $24 \mathrm{hr}$ postoperative creatinine kinase results from their respective preinduction values.

Twenty-four hours later, one of the authors, blinded to the intraoperative management, assessed the myalgia according to a structured questionnaire and graded it by a four point scale described by White (Table I). ${ }^{9}$ This was repeated at $48 \mathrm{hr}$. Patients who were discharged before the 48 hr assessment were contacted by telephone. Changes in creatinine kinase from time 0 to $24 \mathrm{hr}$ were analysed by one-factor analysis of variance (ANOVA) followed by the $t$ test with the Bonferrini modification; changes in potassium were analysed using the KruskalWallis test as the spread of values for the atracurium group did not follow a normal distribution. Fasciculation and myalgia scores were analysed using the Chi-squared tests. A $P$ value of $<0.01$ was considered significant when the $t$ test with Bonferrini modification was done and $P<0.05$ was considered significant for the others. 
TABLE I Grading system for postoperative myalgia by White ${ }^{9}$

\begin{tabular}{lll}
\hline 1 & Nil & No pain \\
2 & Slight & Pain at one site but not causing disability \\
3 & Moderate & Pain at more than one site but not causing disability \\
4 & Severe & Pain at more than one site and causing disability. \\
& e.g., difficulty in getting out of bed, turning head. \\
\hline
\end{tabular}

TABLE II Anthropometric data for patients in the four groups. Data is presented as mean $\pm \mathrm{SD}$

\begin{tabular}{lllll}
\hline Group & $C$ & $A$ & $L$ & $A L$ \\
\hline Age $(\mathrm{yr})$ & $34.9 \pm 11.4$ & $34.1 \pm 10.2$ & $36.4 \pm 12.7$ & $38.1 \pm 11.3$ \\
Sex $(\mathrm{M} / \mathrm{F})$ & $12 / 8$ & $10 / 10$ & $12 / 8$ & $9 / 11$ \\
Weight $(\mathrm{kg})$ & $62.2 \pm 7.5$ & $61.2 \pm 8.2$ & $63.5 \pm 10.1$ & $63.1 \pm 7.5$ \\
\hline
\end{tabular}

Group C-control group, A-Atracurium group, L-Lidocaine group, AL-Atracurium and lidocaine group

TABLE III Mean \pm s.d.results for serum potassium and creatinine kinase concentrations

\begin{tabular}{lcccc}
\hline & \multicolumn{2}{c}{ Potassium $\left(m E q \cdot l^{-1}\right)$} & \multicolumn{2}{c}{ Creatinine kinase $\left(I U \cdot 1^{-1}\right)$} \\
\hline Group & Preinduction & Calculated increase & Preinduction & Calculated 24 br increase \\
\hline C & $3.94 \pm 0.33$ & $0.36 \pm 0.23$ & $106.05 \pm 37.89$ & $56.05 \pm 16.98$ \\
A & $3.84 \pm 0.27$ & $0.28 \pm 0.06$ & $90.15 \pm 24.86$ & $20.93 \pm 9.03^{*}$ \\
L & $4.06 \pm 0.30$ & $0.37 \pm 0.22$ & $104.10 \pm 36.50$ & $45.01 \pm 9.08$ \\
AL & $3.82 \pm 0.45$ & $0.33 \pm 0.13$ & $96.56 \pm 28.50$ & $22.35 \pm 8.3^{*}$ \\
\hline
\end{tabular}

Group C-control group, A-Atracurium group, L-Lidocaine group, AL-Atracurium and lidocaine group ${ }^{\star} P<0.01$ compared with control

TABLE IV Incidence and severity of fasciculations

\begin{tabular}{lrrrr}
\hline Group & $C$ & $A$ & $L$ & $A L$ \\
\hline None (n) & 0 & 12 & 3 & 14 \\
Mild (n) & 1 & 4 & 8 & 2 \\
Moderate (n) & 12 & 2 & 5 & 4 \\
Severe (n) & 7 & 2 & 4 & 0 \\
\hline Total (\%) & 100 & $40^{*}$ & 85 & $30^{*}$
\end{tabular}

Group C-control group, A-Atracurium group, L-Lidocaine group, AL- Atracurium and lidocaine group. ${ }^{*} P<0.05$ compared to control. $n=$ number of subjects in each group

\section{Results}

The four groups were comparable with regard to age, weight and sex distribution (Table II).

The mean preinduction serum potassium concentration and the increase in serum potassium after succinylcholine administration showed no difference $(P<0.05)$ among the groups (Table III).

The mean preinduction serum creatinine kinase concentrations were similar. The increases in serum creatinine kinase observed $(P<0.01)$ in Groups $A$ and $\mathrm{AL}$ were lower than the increases observed in the control group (C) and group L (Table III). No differences were observed between groups $\mathrm{L}$ and $\mathrm{C}$ or between groups $\mathrm{A}$ and $\mathrm{AL}$.

The incidence of fasciculations of $40 \%$ in Group A and $30 \%$ in Group AL was not different $(P<0.05)$ (Table IV). However, the incidence of fasciculations was lower in these two groups than in groups C $(100 \%)$ and $\mathrm{L}(85 \%)$ individually.
At $24 \mathrm{hr}, 75 \%$ of the patients in the control group had myalgia compared with $35 \%$ in group $A, 30 \%$ in group $\mathrm{L}$ and $5 \%$ in group $\mathrm{AL}$ (Table V). The difference between the control group and the other three groups was significant $(P<0.05)$; no difference was noted between groups $A$ and $L$. The incidence of myalgia was lower in group AL than in groups A and L. Similar results for the incidence of myalgia were observed at $48 \mathrm{hr}$.

\section{Discussion}

The principal findings of this study were a greater incidence of myalgia in the control group than in the separate atracurium and lidocaine groups while the group receiving atracurium and lidocaine together had the lowest incidence. The increase in serum creatinine kinase concentration and the incidence of fasciculations were similar in the lidocaine and control groups. The rise in creatinine kinase and the incidence of fasciculations, though similar between the atracurium and the atracurium-lidocaine groups, were lower than control. All the groups showed no difference in the rise of serum potassium measured five minutes after administering succinylcholine.

In his metaanalysis, $\mathrm{Pace}^{2}$ noted that the incidence of postoperative myalgia could be reduced by using nondepolarising agents, lidocaine and high dose benzodiazepines. Melnick $e t a l .{ }^{15}$ found the incidence of postoperative myalgia decreased from $22-25 \%$ when $1.5 \mathrm{mg} \cdot \mathrm{kg}^{-1}$ lidocaine and $0.06 \mathrm{mg} \cdot \mathrm{kg}^{-1} \mathrm{~d}$-tubocurarine were used separately, to $8 \%$ when they were 
TABLE $\mathrm{V}$ Incidence and severity of myalgia

\begin{tabular}{lrrrrrrrrr}
\hline & \multicolumn{3}{c}{ Day 1 } & \multicolumn{4}{c}{ Day 2 } \\
\hline Group & $C$ & $A$ & $L$ & $A L$ & $C$ & $A$ & $L$ & $A L$ \\
\hline None (n) & 5 & 13 & 14 & 19 & 7 & 15 & 13 & 20 \\
Mild (n) & 3 & 4 & 3 & 1 & 4 & 4 & 7 & 0 \\
Moderate (n) & 8 & 2 & 2 & 0 & 7 & 1 & 0 & 0 \\
Severe (n) & 4 & 1 & 1 & 0 & 2 & 0 & 0 & 0 \\
\hline Total incidence (\%) & 75 & $3^{*}$ & $30^{*}$ & $5^{* *}$ & 65 & $25^{*}$ & $35^{*}$ & $0^{* *}$ \\
\hline
\end{tabular}

Group C-control group, A-atracurium group, L-lidocaine group, AL-atracurium and lidocaine group. $\mathrm{n}=$ number of subjects in cach group. ${ }^{\star} P<0.05$ compared with control; ${ }^{*} P<0.05$ compared with the other three groups.

used together. Cannon, in a recent editorial, ${ }^{17}$ suggested that combining two agents may prove to be the most useful method to reduce fasciculation and myalgia after succinylcholine.

An increase in creatinine kinase, indicating muscle damage due to succinylcholine, has been described previously. $3,5-7$ This rise is often noted $24 \mathrm{hr}$ after succinylcholine administration. $3,5,6,7,19,20$ Non depolarising agents such as $\mathrm{d}$-tubocurarine ${ }^{3}$ and alcuronium ${ }^{20}$ have been shown to reduce creatinine kinase rise. Laurence $^{20}$ found alcuronium to be effective while lidocaine was not in preventing the increase in creatinine kinase concentration when intermittent succinylcholine was used.

An increase in serum potassium concentration between $0.3-0.54 \mathrm{mEq} \cdot \mathrm{l}^{-1}$ after a single dose of succinylcholine has been documented. ${ }^{1,3,4}$ As Weintraub ${ }^{4}$ found the peak rise in serum potassium occurred one to seven minutes after administering succinylcholine we measured serum potassium levels five minutes after succinylcholine.

Both Stoelting and Peterson ${ }^{3}$ and Ferres et al. ${ }^{8}$ found the elevation of serum potassium was similar with or without pretreatment with nondepolarising agents. Mcloughlin ${ }^{15}$ found a reduction in the incidence of myalgia while noting no difference in the rise of serum potassium when pretreatment with d-tubocurarine was compared with controls. Though Chatterji ${ }^{11}$ found a restriction in the rise of serum potassium and the incidence of myalgia when lidocaine $2 \mathrm{mg} \cdot \mathrm{kg}^{-1}$ was used as pretreatment for $1 \mathrm{mg} \cdot \mathrm{kg}^{-1}$ succinylcholine, we did not observe a similar reduction in the rise of serum potassium using $1.5 \mathrm{mg} \cdot \mathrm{kg}^{-1}$ lidocaine as pretreatment for 1.5 $\mathrm{mg} \cdot \mathrm{kg}^{-1}$ succinylcholine. This variance in observation could be due to differing doses being used.

Hartman, Fiamengo and Riker ${ }^{18}$ suggested that fasciculations were caused by antidromically conducted axonal depolarisations initiated by the agonist action of succinylcholine on prejunctional nicotinic receptors at the neuromuscular junction, leading to the simultaneous contraction of all muscle fibres of individual motor units. Non depolarising neuromuscular agents which bind to these prejunctional nicotinic receptor sites can thus block this effect of succinylcholine.

In our study, though pretreatment with atracurium and lidocaine together or atracurium alone were equally effective in preventing the increase in serum creatinine kinase, combining the two agents was more effective in reducing myalgia. Pretreatment with lidocaine did not prevent the rise in serum creatinine kinase despite reducing myalgia. This supports Cannon's suggestion ${ }^{17}$ that myalgia and muscle damage may not be related.

As pretreatment with nondepolarising agents may affect intubating conditions, it has been suggested that a larger dose of succinylcholine be given to those who are pretreated. ${ }^{21}$ However there is controversy on whether increasing the succinylcholine dose accentuates the side effects. ${ }^{3,22} \mathrm{We}$ used $1.5 \mathrm{mg} \cdot \mathrm{kg}^{-1}$ succinylcholine, the dose recommended when a nondepolarising agent is used for precurarisation, ${ }^{13,14,21}$ and found no obvious effect on intubating conditions. This dose may have caused increased myalgia in the placebo group, thus biasing the results in favour of the atracurium and the atracurium-lidocaine groups. Further, as some patients took paracetemol especially on the second postoperative day, we acknowledge that the measurement of postoperative myalgia could be affected.

There have been numerous studies comparing various nondepolarising agents for precurarisation. $8,10,12,13,14$ Atracurium has been shown to be one of the more effective nondepolarising agents. ${ }^{2,14}$ Sosis $^{14}$ comparing atracurium and d-tubocurarine suggested that 0.025 $\mathrm{mg} \cdot \mathrm{kg}^{-1}$ atracurium given three to five minutes before succinylcholine may be better for post-succinylcholine myalgia while Manchikanti ${ }^{13}$ using $0.05 \mathrm{mg} \cdot \mathrm{kg}^{-1}$ atracurium three minutes before succinylcholine showed effectiveness against both postoperative myalgia and fasciculations. Thus precurarisation with $0.05 \mathrm{mg} \cdot \mathrm{kg}^{-1}$ atracurium three minutes before succinylcholine was chosen.

Lidocaine at doses ranging from 1.5 to $6 \mathrm{mg} \cdot \mathrm{kg}^{-1}$ is another effective agent against myalgia. ${ }^{2,11,15,16}$ Melnick $^{15}$ using $1.5 \mathrm{mg} \cdot \mathrm{kg}^{-1}$ lidocaine 15 to $30 \mathrm{sec}$ before succinyl- 
choline found it to be effective against postoperative myalgia while Laurence ${ }^{20}$ using the same amount two to three minutes before succinylcholine found it to be ineffective in reducing postoperative myalgia. Hence our choice of lidocaine dose and timing.

No separate adverse effects were noted with this study. Problems, such as lidocaine induced changes in the heart rate or rhythm or blood pressure, were mot noticed. Antagonism of succinylcholine induced relaxation was not studied. Clinically at no time was intubation found to be difficult due to incomplete relaxation.

In summary, the increase in serum potassium concentration could not be reduced by any of the pretreatment regimens. Attenuation of the incidence of fasciculations and the rise in creatinine kinase were similar when atracurium was used alone or together with lidocaine. However, the incidence of myalgia was reduced when atracurium and lidocaine were used together as pretreatment.

\section{Acknowledgements}

Our thanks to the ENT doctors, Anaesthesia medical officers and laboratory technicians for their help in the completion of this study.

We are also grateful to Dr. P. Manninen, Department of Anaesthesia, The Toronto Hospital, Western Division, University of Toronto, for reviewing the manuscript.

\section{References}

1 Bourne JG, Collier HOJ, Somers GF. Succinylcholine (succinoylcholine) muscle relaxant of short action. Lancet 1952; 1: 1225-9.

2 Pace NL. Prevention of succinylcholine myalgias: a meta-analysis. Anesth Analg 1990; 70: 477-83.

3 Stoelting $R K$, Peterson $C$. Adverse effects of increased succinylcholine dose following d-tubocurarine pretreatment. Anesth Analg 1975; 54: 282-8.

4 Weintraub HD, Heisterkamp DV, Cooperman LH. Changes in plasma potassium concentration after depolarizing blockers in anaesthetized man. $\mathrm{Br}$ J Anaesth 1969; 41: 1048-52.

5 Tammisto T, Airaksinen $M$. Increase of creatine kinase activity in serum as sign of muscular injury caused by intermittently administered suxamethonium during halothane anaesthesia. Br J Anaesth 1966; 38: 510-5.

6 Innes RKR, Stromme JH. Rise in serum creatine phosphokinase associated with agents used in anaesthesia. Br J Anaesth 1973; 45: 185-90.

7 Charak DS, Dhar CL. Suxamethonium-induced changes in serum creatine phosphokinase. $\mathrm{Br} J$ Anaesth 1981; 53: 955-7.
8 Ferres CJ, Mirakbur RK, Craig HJL, Browne ES, Clarke RSJ. Pretreatment with vecuronium as a prophylactic against post-suxamethonium muscle pain. $\mathrm{Br}$ J Anaesth $1983 ; 55: 735-41$.

9 White DC. Observations on the prevention of muscle pains after suxamethonium. Br J Anaesth 1962; 34: 332-5.

10 Bennetts FE, Khalil KI. Reduction of post-suxamethonium pain by pretreatment with four non- depolarizing agents. Br J Anaesth 1981; 53: 531-6.

11 Chatterji S, Thind SS, Daga SR. Lignocaine pretreatment for suxamethonium. A clinicobiochemical study. Anaesthesia 1983; 38: 867-70.

12 Bennett EJ, Montgomery SJ, Dalal FY, Pritbvi Raj P. Pancuronium and the fasciculations of succinylcholine. Anesth Analg 1973; 52: 892-6.

13 Manchikanti L, Grow JB, Colliver JA, Canella $M G$, Hadley $\mathrm{CH}$. Atracurium pretreatment for succinylcholine-induced fasciculations and postoperative myalgia. Anesth Analg 1985; 64: 1010-4.

14 Sosis M, Broad T, Larijani GE, Marr AT. Comparison of atracurium and $d$-tubocurarine for prevention of succinylcholine myalgia. Anesth Analg 1987; 66: 657-9.

15 Melnick B, Chalasani J, Lim Uy NT, Phitayakorn P, Mallett $S V, R u d y T E$. Decreasing post-succinylcholine myalgia in outpatients. Can J Anaesth 1987; 34: 238-41.

16 Usubiaga JE, Wikinski JA, Usubiaga LE, Molina F. Intravenous lidocaine in the prevention of postoperative muscle pain caused by succinylcholine administration. Anesth Analg 1967; 46: 225-9.

17 Cannon JE. Precurarization (Editorial). Can J Anaesth 1994; 41: 177-83.

18 Hartman GS, Fiamengo SA, Riker WF Jr. Succinylcholine: mechanism of fasciculations and their prevention by $d$-tubocurarine or diphenylhydantoin. Anaesthesiology 1986; 65: 405-13.

19 McLoughlin C, Elliot P, McCartby G, Mirakhur RK. Muscle pains and biochemical changes folowing suxamethonium administration after six pretreatment regimens. Anaesthesia 1992: 47: 202-6.

20 Laurence AS. Myalgia and biochemical changes following intermittent suxamethonium administration. Anaesthesia 1987; 42: 503-10.

21 Cullen DJ. The effect of pretreatment with nondepolarizing muscle relaxants on the neuromuscular blocking action of succinylcholine. Anesthesiology 1971;35: 572-8.

22 Stewart KG, Hopkins PM, Dean SG. Comparison of high and low doses of suxamethonium. Anaesthesia 1991; 46: 833-6. 